\title{
Platelet Glycoprotein Ib: A Zinc-Dependent Binding Protein for the Heavy Chain of High- Molecular-Weight Kininogen
}

\author{
Kusumam Joseph,' Yoshitaka Nakazawa,' Wadie F. Bahou, ${ }^{2}$ \\ Berhane Ghebrehiwet, ${ }^{2}$ and Allen P. Kaplan ${ }^{1}$ \\ ${ }^{1}$ Department of Medicine, Division of Pulmonary, Critical Care, \\ Asthma and Allergy, Medical University of South Carolina, \\ Charleston, South Carolina, U.S.A. \\ ${ }^{2}$ Department of Medicine, State University of New York, Stony \\ Brook, New York, U.S.A.
}

Accepted July 22, 1999.

\begin{abstract}
Domains 3 and 5 of high-molecular-weight kininogen (HK) have been shown to bind to platelets in a zincdependent reaction. However, the platelet-binding proteins responsible for this interaction have not been identified. We have focused on the platelet-binding site for the heavy chain (domain 3), which we approached using a domain 3-derived peptide ligand and isolated binding proteins by affinity chromatography. The domain 3-derived peptide, thrombin, HK, factor XII, as well as antibody to glycocalicin (the $\mathrm{N}$-terminal portion of the $\alpha$ chain of GPIb) recognized a protein at $74 \mathrm{kD}$. We also isolated the thrombin receptor (PAR l) at $45 \mathrm{kD}$, however, none of the above-mentioned ligands bound to this
\end{abstract}

protein. Isolation of platelet membrane proteins using a monoclonal anti-glycocalicin antibody column revealed the same $\mathrm{HK}$ binding protein at $74 \mathrm{kD}$, which was reactive with anti-GPIb and represents a GPIb fragment. By photoaffinity labeling, HK interacted with membrane GPIb, which was then isolated in native form (135 kD) along with $\mathrm{gClqR}$, a ligand for the HK light chain. Finally, ${ }^{125} \mathrm{I}-\mathrm{HK}$ binding to platelets was significantly inhibited by the anti-GPIb antibody. These results suggest that the GPIb $\alpha$ chain, a known thrombin binding protein, is also one of the zinc-dependent platelet membrane binding sites for HK domain 3.

\section{Introduction}

The plasma kinin-forming cascade consists of factor XII, high-molecular-weight kininogen (HK), and prekallikrein, which interact to generate the vasoactive peptide bradykinin. Activated factor XII converts prekallikrein to kallikrein and kal-

Y. Nakazawa is a Visiting Scientist from the Institute of Bio-Active Science, Nippon Zoki Pharmaceutical Co. Ltd., Hyogo, Japan.

Address correspondence and reprint requests to: Allen $P$. Kaplan, M.D., Medical University of South Carolina, Department of Medicine, Division of Pulmonary/Critical Care and Allergy/Clinical Immunology, 171 Ashley Ave., Charleston, SC 29425-2220, U.S.A. Phone: 843-792-2468; Fax: 843-792-2488; E-mail: kaplana@musc.edu likrein digests HK to release bradykinin. Prekallikrein circulates bound to $\mathrm{HK}$ and $\mathrm{HK}$ also serves as a cofactor for prekallikrein activation by factor XIIa (1).

HK possesses six domains: the first three are homologous to cysteine protease inhibitors, the fourth domain includes the bradykinin moiety, and domains 5 and 6 interact with negatively charged surfaces and with prekallikrein or factor XI, respectively. HK has been shown to bind to platelets by its heavy and light chains (2-4) and $15-50 \mu \mathrm{M}$ zinc is required for binding. The isolated heavy and light chains derived from kinin-free kininogen 
can each interact with platelets (4) as well as endothelial cells (5) and those interactions are dependent upon peptides within domains 3 and 5 , respectively $(6,7)$.

HK has been shown to inhibit thrombininduced platelet aggregation (8) and we have presented preliminary data to suggest a direct interaction of HK with GPIb (9). This is consistent with a recent report in which Bradford et al. (10) showed that HK does not inhibit thrombindependent aggregation of Bernard-Soulier platelets, which lack the GPIb-IX-V complex, and that several antibodies to the complex inhibit HK binding. Although thrombin binds to GPIb, the functional thrombin receptor (PAR-1) is a separate protein, which is cleaved by thrombin, and the newly exposed $\mathrm{N}$-terminus participates in cell activation. Thus HK may interact with the GPIb-IX-V complex to inhibit functions of PAR-1 or it might interact with both proteins.

In this report, we identify the extracellular portion of the $\alpha$ chain of platelet membrane GPIb (glycocalicin) as a binding site, which interacts with domain 3 of $\mathrm{HK}$ as well as coagulation factor XII in a zinc-dependent reaction. A molecule of $74 \mathrm{kD}$ was initially isolated by affinity chromatography using HK or antibody to glycocalicin as ligand. The intact $\alpha$ chain was then isolated by photoaffinity labeling. We also identified PAR-1 within the HK affinity chromatography eluate; however, there is no evident binding of biotinylated HK or factor XII to it.

\section{Materials and Methods}

\section{Materials}

Purified HK, factor XII, and $\alpha$ thrombin were purchased from Enzyme Research Laboratories (South Bend, IN). A domain 3-binding peptide of HK [LDC-27, sequence LDCNAEVYVVPWEKKIYPTVNCQPLGM (7)] was synthesized by the Center for Analysis and Synthesis of Macromolecules, State University of New York, Stony Brook. Polyclonal antibody to the thrombin receptor (11) and monoclonal antibody (MAb) to the $\mathrm{gClq}-\mathrm{R}(12)$ were prepared as described previously. Monoclonal antibody to glycocalicin (6D 1) was a gift from Dr. Barry Coller (Mount Sinai Medical Center, New York, NY). It is directed to the $45 \mathrm{kD}$ amino-terminal domain of the $\alpha$ chain of glycoprotein $\mathrm{Ib}$.
Preparation of LDC-27 and Anti-glycocalicin Antibody Affinity Columns

Peptide LDC-27 (reduced and blocked) or antiglycocalicin antibody was coupled with $3 \mathrm{M}$ Emphaze Biosupport Medium ABl (Pierce Chemical, Rockford, IL) according to the manufacturer's recommendations as described previously (12). Briefly, $5 \mathrm{mg}$ of the ligand $(5 \mathrm{ml})$ was dialyzed against $0.1 \mathrm{M}$ carbonate buffer, $\mathrm{pH}$ 9.0, and sodium citrate was added to a final concentration of $0.6 \mathrm{M}$. To this, $0.125 \mathrm{~g}$ of dry beads was added and mixed for $2 \mathrm{hr}$ at room temperature. This mixture was poured into a small column and washed with $10 \mathrm{vol}$ of phosphate-buffered saline (PBS). The eluate and the washings were collected to determine coupling efficiency, which was calculated to be $>70 \%$. Then $3 \mathrm{ml}$ of $3 \mathrm{M}$ ethanolamine, $\mathrm{pH} 9.0$, was added to the column, the column was closed at both ends, and mixed end-over-end for $2.5 \mathrm{hr}$ at room temperature. The column was then washed sequentially with 10 vol each of PBS, $1 \mathrm{M} \mathrm{NaCl}$, and PBS. A control column was also made similarly with no ligand.

\section{Purification of Platelet Membrane Proteins}

Platelet packs were obtained from the blood bank and were diluted 1:1 with PBS containing $10 \mathrm{mM}$ EDTA (PBS-EDTA) and centrifuged at $2000 \times g$. The supernatant was discarded and the pellet resuspended in PBS-EDTA and washed three times. The pellet was then resuspended and centrifuged at $800 \times g$ and the supernatant containing platelets was collected and pelleted. The final pellet was resuspended in homogenization buffer [10 mM Hepes, $150 \mathrm{mM} \mathrm{NaCl}, 2 \mathrm{mM}$ phenylmethylsulfonylfluoride (PMSF), $\quad 1 \quad \mu \mathrm{M}$ aprotinin, $1 \mu \mathrm{M}$ pepstatin, $1 \mathrm{mM}$ EDTA, $0.1 \%$ soy bean trypsin inhibitor (SBTI)], and sonicated using a Heat Systems/Ultrasonics (model W225R) sonicator continuously for $2 \mathrm{~min}$ on ice and the sonicate centrifuged at $50,000 \times g$ for 1 $\mathrm{hr}$. The pellet, containing the membrane fraction, was resuspended in homogenization buffer containing $1 \%$ Triton $\mathrm{X}-100$ and kept at $4^{\circ} \mathrm{C}$ overnight with gentle mixing. This suspension was centrifuged at $50,000 \times g$ for $\mathrm{l} \mathrm{hr}$. The supernatant, containing solubilized membrane components, was collected and dialyzed against dialysis buffer (homogenization buffer without SBTI and EDTA) containing $0.1 \%$ Triton X-100. This membrane lysate was applied to the affinity columns and the flow-through was collected. The column was washed with dialysis buffer,

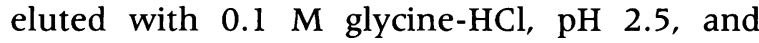


$0.5-\mathrm{ml}$ fractions were collected. The column was then washed and re-equilibrated with dialysis buffer containing $50 \mu \mathrm{M}$ zinc chloride. The initial effluent was also made to $50 \mu \mathrm{M}$ in zinc and was applied to the column. The column was again washed and eluted. Both the eluates were neutralized to $\mathrm{pH} 7.0$ by adding a predetermined quantity of $1 \mathrm{M}$ Tris- $\mathrm{HCl}(\mathrm{pH} \mathrm{9.0)}$ to each tube. Elution was monitored by protein determination and by dot blot using biotinylated peptide. A control column without the ligand was also processed in a similar manner.

\section{Biotinylation of Proteins and Peptides}

Biotinylation of proteins and peptides was performed employing NHS-LC-biotin (Pierce) according to the following procedure. Proteins or peptides to be labeled $(1 \mathrm{mg} / \mathrm{ml})$ were first dialyzed against $2 \times 1$ liter of $0.2 \mathrm{M} \mathrm{NaHCO}_{3}$ buffer (pH 8.3). Labeling was initiated by addition of 50 $\mu \mathrm{l}$ of a $1 \mathrm{mg} / \mathrm{ml}$ solution of biotin freshly dissolved in dimethyl sulfoxide (DMSO). The reaction was allowed to proceed for $4 \mathrm{hr}$ at room temperature with constant but gentle tumble mixing, after which the reaction was stopped and the protein dialyzed, first against 1 liter of the initial dialysis buffer then against $2 \times 1$ liter PBS, $\mathrm{pH}$ 7.5. The degree of biotinylation was verified by ELISA using wells coated with various dilutions of the labeled protein and probing with alkaline phosphatase-conjugated streptavidin (AP-STRAV) or ExtrAvidin (AP-XTRAV).

\section{Iodination of $\mathrm{HK}$}

HK was iodinated with $\mathrm{Na}^{125} \mathrm{I}$ by iodobeads (Pierce) according to manufacturer's recommendations as modified by Nishikawa et al. (13). Following iodination, ${ }^{125} \mathrm{I}$-labeled HK was separated on a desalting column (Econo-Pac $10 \mathrm{DG}$, Bio-Rad, Hercules, CA). Specific labeling, determined by trichloroacetic acid precipitation following addition of bovine serum albumin (BSA) as carrier protein, ranged from 2 to $2.5 \times 10^{9}$ $\mathrm{cpm} / \mathrm{mg}$ protein. HK thus labeled did not lose its coagulant activity, determined according to Proctor and Rapaport (14), which was $12 \mathrm{U} / \mathrm{mg}$, where $1 \mathrm{U}$ is defined as the coagulant activity present in $1 \mathrm{ml}$ of pooled normal human plasma.

\section{Electrophoreses and Western Blot Analyses}

SDS-polyacrylamide gel electrophoresis (PAGE) was performed using the buffer system of Laem- mli (15). After electrophoresis, the gels were stained with Coomassie brilliant blue, destained, and dried. For Western blot and ligand blot analyses, the separated proteins were electrotransferred to nitrocellulose membranes and probed with MAbs or biotinylated ligands at a concentration of 0.5 to $1 \mu \mathrm{g} / \mathrm{ml}$. Bound probes were visualized by alkaline phosphatase-conjugated secondary antibodies or alkaline phosphataseconjugated avidin.

\section{Dot Blot Analyses}

Dot blot analyses were performed using a dot blot apparatus (Bio-Rad). Samples ( 0.5 to $1 \mu \mathrm{g}$ of proteins) were added to the wells and dried under vacuum. The nitrocellulose membrane was removed from the apparatus and incubated $(1 \mathrm{hr}$ at room temperature) in PBS containing $1 \%$ BSA to block the free sites, washed three times in PBST (PBS $+0.05 \%$ Tween 20 ), and reacted with a predetermined dilution of the biotinylated ligand or monospecific antibody. After $\mathrm{l} \mathrm{hr}$ at room temperature, the membrane was washed and the bound ligand probed by sequential reaction ( 1 hr each), first with alkaline phosphataseconjugated avidin or secondary antibody followed by a substrate solution (BCIP/NBT, Kirkegaard \& Perry Laboratories). After full color development was achieved, the reaction was stopped by first rinsing the residual precipitates from the membrane with PBS, followed by washing with PBS-E (PBS + 1 mM EDTA) for 15 min.

\section{Protein Determinations}

Protein concentrations were determined by the method of Bradford (16); for proteins containing nonionic detergents, the detergent-compatible, bicinchoninic acid-dependent protein assay (17) was used.

\section{Preparation of Washed Platelets for Binding Assay}

Blood was obtained from normal healthy adult human donors and mixed with one-sixth volume of acid citrate dextrose. The citrated blood was centrifuged at $800 \times g$ for $20 \mathrm{~min}$ at $4^{\circ} \mathrm{C}$ to obtain platelet-rich plasma, which was collected and centrifuged again at $2000 \times g$ for $10 \mathrm{~min}$ at $4^{\circ} \mathrm{C}$. The platelet pellet was gently suspended in the binding buffer ( $10 \mathrm{mM}$ HEPES, $11 \mathrm{mM} \mathrm{KCl}$, $1 \mathrm{mM} \mathrm{MgCl} 2,1 \mathrm{mg} / \mathrm{ml} \mathrm{BSA}, \mathrm{pH}$ 7.4) and gel filtered over Sepharose CL-2B in a $9 \times 2.5 \mathrm{~cm}$ 
column that had been equilibrated with the same binding buffer. Platelets were eluted at the void volume.

Binding of ${ }^{125} \mathrm{I}-\mathrm{HK}$ to Platelets and Its Inhibition by Anti-GPIb Antibody

All binding studies were performed at $37^{\circ} \mathrm{C}$, without stirring. Washed platelets were incubated in the binding buffer containing labeled $\mathrm{HK}$ in the presence or absence of $50 \mu \mathrm{M}$ zinc. Aliquots were removed at various time points and centrifuged through a silicone oil barrier to separate the platelets from the unbound proteins, and the bound radioactivity was determined. For inhibition studies, platelets were preincubated with anti-GPIb antibody $(10 \mu \mathrm{g} / \mathrm{ml})$ or nonimmune IgG $(10 \mu \mathrm{g} / \mathrm{ml})$ for $20 \mathrm{~min}$. Each measurement was in triplicate and the experiments were repeated three times. The mean and standard deviation was determined and inhibition compared with the binding of ${ }^{125} \mathrm{I}-\mathrm{HK}$ in the presence of nonimmune IgG.

\section{Photoaffinity Labeling}

Photoaffinity labeling of cells was performed using sulfosuccinimidyl-2-[6-(biotinamido)-2(p-azidobenzamido)-hexanoamido] ethyl-1, $3^{\prime}$ dithiopropionate (Sulfo-SBED, Pierce) according to the manufacturer's recommendations. Briefly, HK $(5 \mathrm{mg})$ in $0.1 \mathrm{M}$ PBS $(0.5 \mathrm{ml})$ was mixed with $11 \mu$ l of Sulfo-SBED solution (1.12 $\mathrm{mg}$ in $25 \mu \mathrm{l}$ DMSO) and incubated at room temperature for $30 \mathrm{~min}$. The reaction mixture was then dialyzed to remove the unreacted Sulfo-SBED. This modified HK was then added to the cells and allowed to react for $15 \mathrm{~min}$ at room temperature. The mixture was photolized with a long-wave UV lamp (365 nm) at a distance of $5 \mathrm{~cm}$ for $5 \mathrm{~min}$. Cells were then lysed and the disulfide bond of sulfo-SBED was cleaved by dithiothreitol, resulting in a biotin label attached to any HK binding protein conjugated as a result of photoactivation. The biotinylated binding protein(s) were then isolated using avidin affinity chromatography.

\section{Results}

Interaction of Platelet Membrane Proteins with an HK Peptide Derived from Domain 3

A solubilized platelet membrane preparation in Hepes-buffered saline (10 mM Hepes, 137 mM

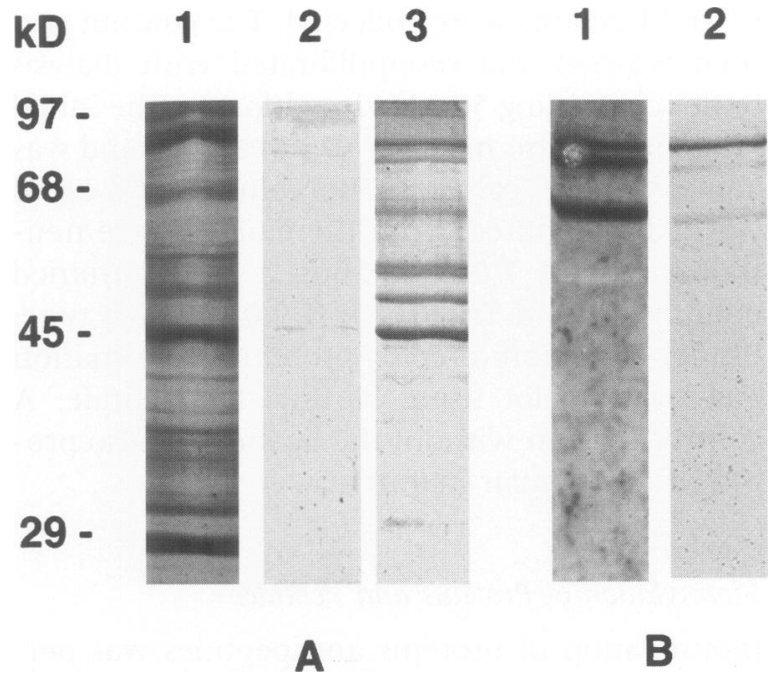

Fig. 1. SDS-PAGE analysis of proteins eluted from the LDC-27 affinity column. Fractions that reacted with LDC-27 were pooled, concentrated, and subjected to a $10 \%$ SDS-polyacrylamide gel (A) as well as ligand blot (B) analysis. In A, the gel was stained with Coomassie blue after electrophoresis. Lane 1 is the starting platelet membrane preparation, lane 2, the eluate from LDC-27 affinity column in the absence of zinc, and lane 3, the eluate from LDC-27 affinity column in the presence of zinc. (B) Ligand blot of the eluate from the affinity column in the presence of zinc using biotinylated HK (lane 1), and biotinylated LDC-27 (lane 2).

$\mathrm{NaCl}, 4 \mathrm{mM} \mathrm{KCl}, 11 \mathrm{mM}$ glucose), containing 2 mM PMSF, $1 \mu \mathrm{M}$ aprotinin, $1 \mu \mathrm{M}$ pepstatin, and $0.1 \%$ SBTI, was passed over an affinity column prepared with the heavy chain of $\mathrm{HK}$ (LDC-27) in the presence or absence of $50 \mu \mathrm{M}$ zinc and the bound proteins were eluted. An aliquot of each eluate fraction was spotted onto a nitrocellulose membrane. The membrane was blotted with biotinylated HK, and developed with alkaline phosphatase-conjugated avidin followed by reaction with BCIP/NBT. The positive fractions were then pooled, concentrated, and analyzed by SDS-PAGE (Fig. 1). In the presence of zinc, more prominent protein bands were obtained than in its absence and the major bands had a molecular weight of $45 \mathrm{kD}$ or greater (Fig. 1A, lane 3). Biotinylated HK bound to proteins at $68 \mathrm{kD}$ and a doublet at 72 and $74 \mathrm{kD}$ (Fig. 1B, lane 1), whereas biotinylated LDC-27 showed prominent binding to the band at $74 \mathrm{kD}$ (Fig. 1B, lane 2). Thus the $74 \mathrm{kD}$ protein is the major binding moiety for the domain 3 peptide, while $\mathrm{HK}$ binds to at least two other additional proteins that were 


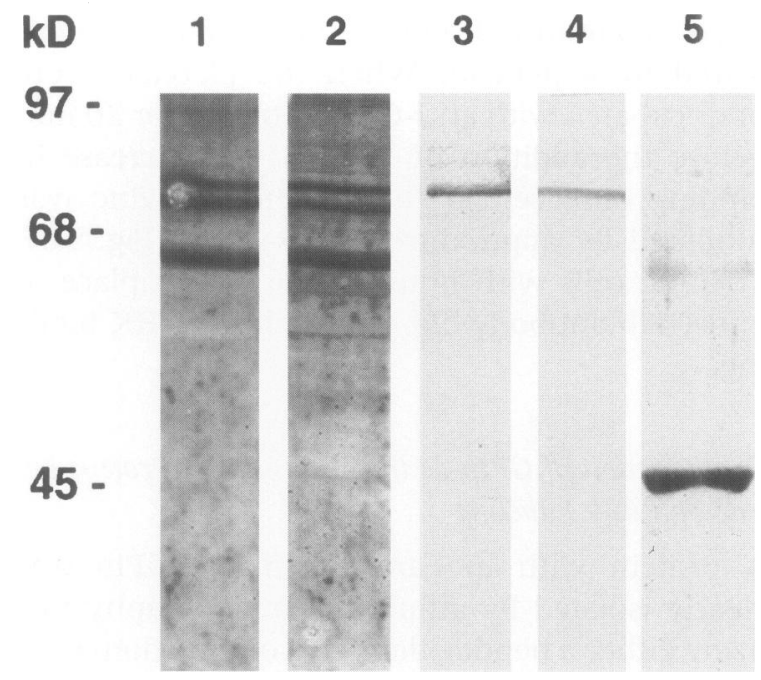

Fig. 2. Purified membrane proteins from the LDC-27 affinity column binds to HK, factor XII, and thrombin. The eluate from an LDC-27 affinity column in the presence of zinc was electrophoresed on a $10 \%$ gel and transferred to a nitrocellulose membrane. After transfer, the membrane was cut into strips and probed with either biotinylated HK (lane 1), biotinylated factor XII (lane 2), biotinylated thrombin (lane 3), antibody to GPIb (lane 4), or antibody to the thrombin receptor (lane 5).

co-isolated with it. Passage of a solubilized membrane preparation (in the presence of zinc) over an affinity column prepared without any ligand followed by elution and then immunoblot with either biotinylated LDC-27 or biotinylated $\mathrm{HK}$, revealed no identifiable bands.

We next tested factor XII for binding and demonstrated characteristics virtually identical to those of HK, with binding to a major band of $68 \mathrm{kD}$ and a doublet at 72 and $74 \mathrm{kD}$ on ligand blot analysis (Fig. 2, lanes 1, 2). However, biotinylated thrombin as well as antibody to GPIb bound to the uppermost band at $74 \mathrm{kD}$ (Fig. 2, lanes 3,4$)$. An antibody to the thrombin receptor, however, bound to a band at $45 \mathrm{kD}$ (Fig. lA, lane 3 ), which did not bind HK, factor XII, or thrombin.

To confirm that the $74 \mathrm{kD}$ protein identified corresponds to GPIb, we prepared an affinity column using anti-glycocalicin antibody $(18,19)$ directed to the $\mathrm{N}$-terminal region of the GPIb $\alpha$ chain and purified proteins from a platelet membrane lysate. The proteins eluted from the column were analyzed on SDS-PAGE. A Coomassie blue-stained gel showed three major bands at 66 , 72 , and $74 \mathrm{kD}$ (Fig. 3, lane 2). Ligand blot analysis with biotinylated HK in the presence of zinc

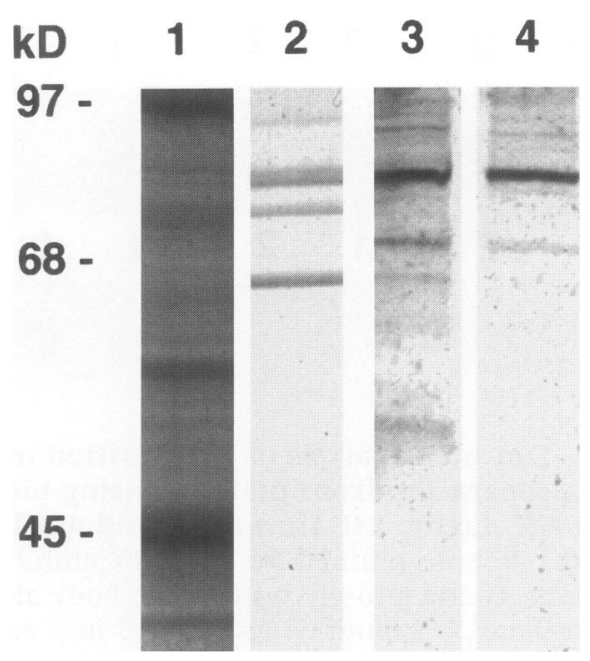

Fig. 3. Proteins purified from an anti-glycocalicin antibody affinity column binds to HK. The proteins eluted from an anti-glycocalicin antibody affinity column were subjected to SDS-PAGE analysis. The gel was stained with Coomassie blue (lane 1, starting platelet membrane preparation; lane 2 , eluate from the anti-glycocalicin antibody column). The proteins were transferred to nitrocellulose membrane and probed with anti-GPIb antibody (lane 3) and biotinylated HK (lane 4).

or Western blot with anti-GPIb revealed binding to the $74 \mathrm{kD}$ moiety (Fig. 3, lanes 3,4 ) as well as to a lesser band at $69 \mathrm{kD}$.

\section{Zinc-Dependent Binding of $\mathrm{HK}$ and Factor XII to Purified Membrane Protein}

Purified membrane proteins from the peptide affinity column and the anti-glycocalicin antibody affinity column were also compared by dot blot analysis for their binding properties. Biotinylated HK (Fig. 4A,B) as well as biotinylated factor XII (Fig. 4C,D) displayed binding in the presence of zinc and minimal interaction in the absence of zinc. Although nonspecific ion effects may be seen with dot blot analysis, the binding in this case parallels that known to occur using whole cells. Both biotinylated thrombin (Fig. 4E) and anti-GPIb antibody (Fig. 4F) also bound to the eluted proteins; these interactions were independent of zinc. When the purified membrane proteins were replaced by purified IgG, there was no discernable binding.

\section{Binding of $\mathrm{HK}$ to Platelets and Its Inhibition}

Cell-binding studies using ${ }^{125} \mathrm{I}$-HK showed an increase in binding in the presence of zinc reach- 


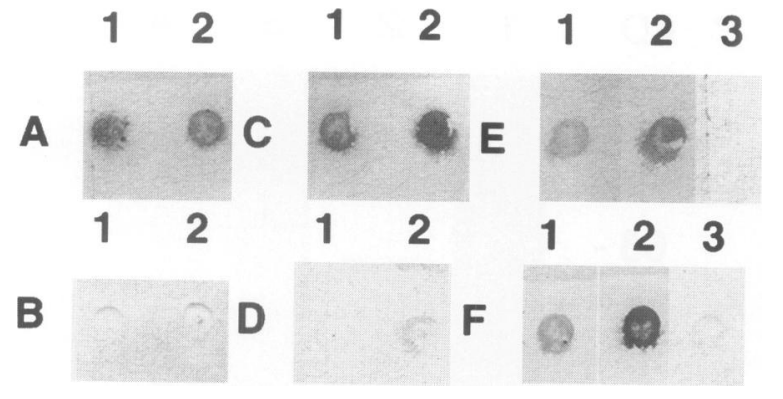

Fig. 4. Dot blot analysis of the purified membrane preparation from platelets using biotinylated HK, factor XII, thrombin, and antibody to GPIb. Proteins purified from the HK affinity column (lane 1) and anti-glycocalicin antibody affinity column (lane 2) or purified IgG (lane 3 in E and F) were spotted onto the nitrocellulose membrane and probed with biotinylated HK $(\mathrm{A}, \mathrm{B})$ and biotinylated Factor XII (C,D). A and C are with zinc while B and $\mathrm{D}$ are without zinc. Binding of biotinylated thrombin (E) and anti-GPIb antibody (F) are shown in the absence of zinc. ing a maximum at about $20 \mathrm{~min}$ (Fig. 5A), followed by a plateau. When the platelets were preincubated with anti-GPIb antibody for $20 \mathrm{~min}$ before the addition of ${ }^{125} \mathrm{I}-\mathrm{HK}$, the increase in binding observed in the presence of zinc was inhibited by approximately 55-60\% (Fig. 5B). Treating cells with nonimmune IgG in place of anti-GPIb antibody did not inhibit the HK binding.

\section{Confirmation of GPIb as the HK Binding Protein by Photoaffinity Labeling}

A protein with the antigenicity of GPIb was clearly isolated by affinity chromatography utilizing either a peptide derived from the domain 3 of HK or anti-glycocalicin antibody. However, the $\alpha$ chain of GPIb has a known molecular weight of $135 \mathrm{kD}$ and we assumed that a fragment of this protein had been isolated. We therefore wished to corroborate the finding by a dif-
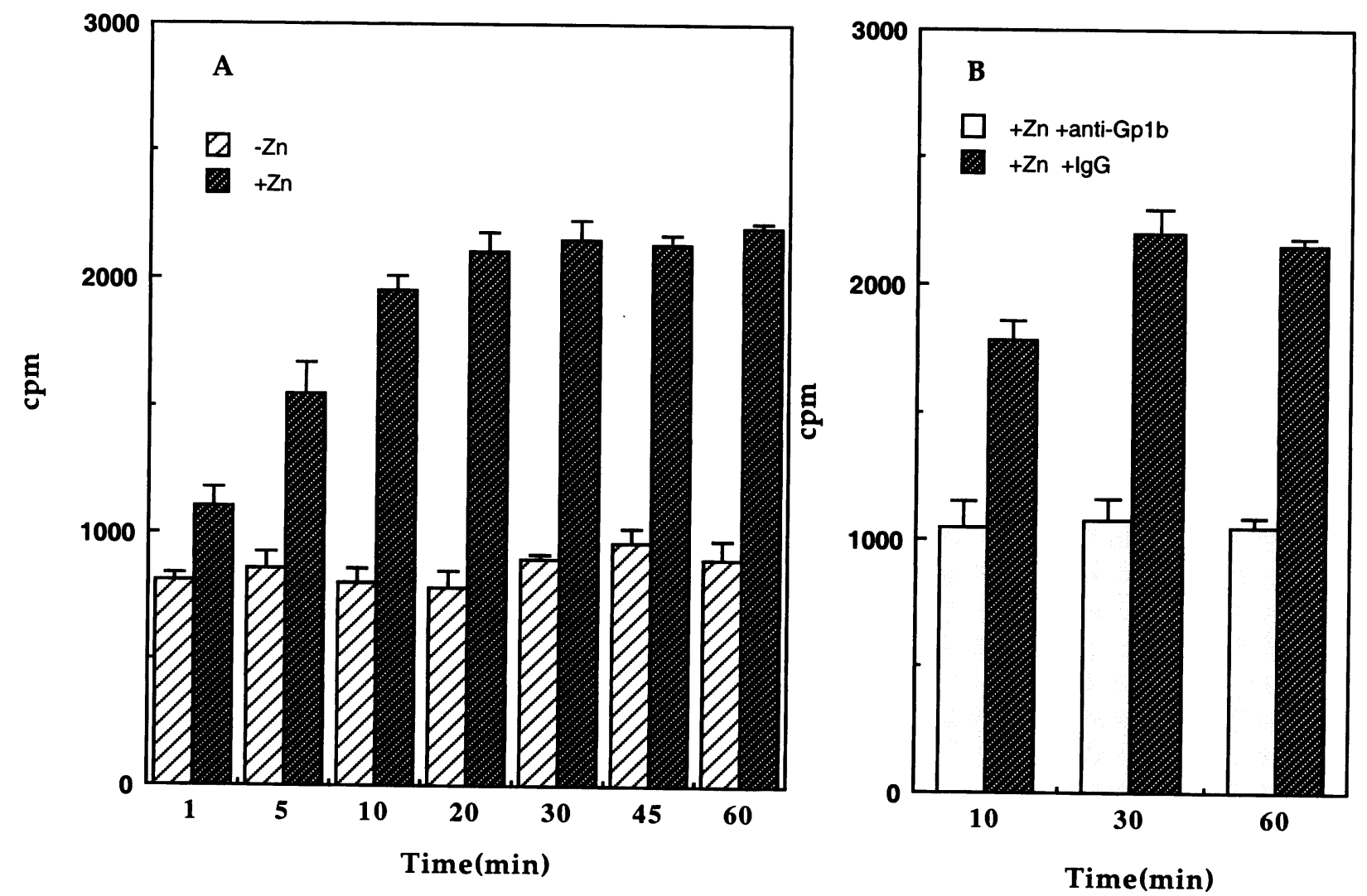

Fig. 5. Inhibition of the zinc-dependent binding of HK to platelets by anti-GPIb antibody. (A) Zincdependent binding of $\mathrm{HK}$ to platelets and (B) its inhibition by anti-GPIb antibody. Washed platelets in binding buffer ( $10 \mathrm{mM}$ Hepes, $137 \mathrm{mM} \mathrm{NaCl}, 4 \mathrm{mM} \mathrm{KCl}, 11 \mathrm{mM}$ glucose, and $0.5 \mathrm{mg} / \mathrm{ml} \mathrm{BSA}$ ) were incubated (unstirred, at room temperature) with ${ }^{125} \mathrm{I}-\mathrm{HK}(20 \mathrm{nM})$ in the presence or absence of $50 \mu \mathrm{M}$ zinc. Aliquots were removed at the indicated times and centrifuged through a silicone oil barrier to separate the platelets from the unbound proteins. For the inhibition experiments, platelets were preincubated with anti-GPIb antibody or nonimmune IgG for $20 \mathrm{~min}$ before the addition of ${ }^{125} \mathrm{I}-\mathrm{HK}$. Results are the mean \pm standard error from three different experiments. 


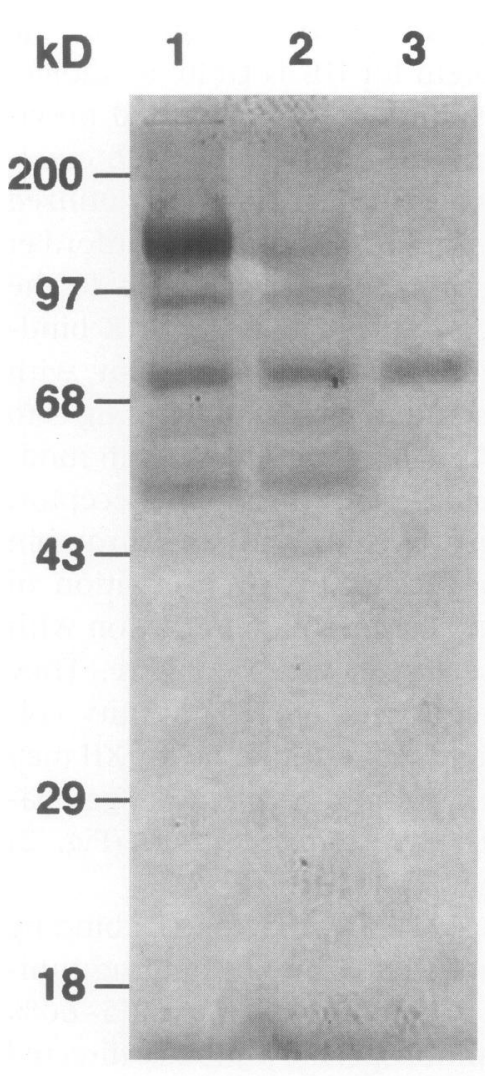

A



B
Fig. 6. Photoaffinity labeling of HK binding proteins on the surface of platelets. Twenty nanometers of biotin-modified HK was interacted with platelets in the presence or absence of $50 \mu \mathrm{M}$ zinc. A separate control includes all reagents in the absence of HK. After photoactivation, cell lysis, and reduction with dithiothreitol, the proteins were examined by $10 \%$ SDS gel electrophoresis with development of bands with alkaline phosphatase conjugated avidin. (A) Lane 1, labeled protein in the presence of HK plus zinc; lane 2, labeled protein in the presence of HK without zinc; lane 3 , a control in the absence of HK. In each instance, the proteins were isolated by avidin-sepharose affinity chromatography and examined by $7 \%$ SDS gel electrophoresis. (B) Lane 1, HK-interacting proteins in the presence of zinc; lane 2, Western blot with anti-GPIb of material in lane 1; lane 3, Western blot with anti-GPlb of interacting proteins in the absence of zinc. ferent method and chose photoaffinity labeling, in which HK is first modified with biotin and then transfers the biotin moiety to surface proteins with which it interacts. Figure $6 \mathrm{~A}$ is a $10 \%$ SDS gel showing the result of HK interaction with the cell in the presence of $50 \mu \mathrm{M}$ zinc (lane 1). Proteins containing biotin were developed with alkaline phosphatase-conjugated avidin. A prominent protein is seen at $135 \mathrm{kD}$; other bands visible are at 95, 71, and $50 \mathrm{kD}$. Lane 2 represents the same photoaffinity experiments in which HK interacts with platelets in the absence of zinc. The same binding pattern is obtained, however, the band at $135 \mathrm{kD}$ is much diminished. Lane 3 is a control in the absence of HK, thus the $71 \mathrm{kD}$ band represents either a reagent or a platelet protein that binds biotin and/or avidin. The proteins represented by lanes 1 and 2 were then purified further by avidin affinity chromatography, and electrophoresed on a $7 \%$ SDS gel (Fig. 6B). Lane 1 represents the eluate from the HK binding experiment in the presence of zinc and developed with avidin-alkaline phosphatase. The very prominent band at $135 \mathrm{kD}$ is seen as doublet. A Western blot of this material with anti-GPIb (lane 2) identifies this band. The eluate of the HK binding experiment in the absence of zinc that was isolated in an identical fashion has a far lesser amount of GPIb (lane 3). Of interest is the finding that the band at $33 \mathrm{kD}$ in lane 1 of Figure $6 \mathrm{~B}$ is $\mathrm{gClqR}$; lane 1 in Figure $6 \mathrm{~A}$ is too dilute to detect it.

\section{Discussion}

High-molecular-weight kininogen (HK) binds to platelets in a zinc-dependent reaction, with binding sites demonstrable on domains 3 and $5(3,4)$. These same domains have been shown to interact with endothelial cells $(6,7)$ and neutrophils (20) and specific peptides have been identified as the sites of interaction with endothelial cells $(6,7)$. Factor XII also binds to endothelial cells (21) and competes with HK for binding indicative of a common binding protein within the cell membrane.

We have focused on the platelet interaction with HK domain 3, since this interaction has been shown to inhibit platelet aggregation if it is 
initiated with a low concentration of thrombin (9). The reaction is specific for thrombin because HK does not inhibit activation induced by other platelet agonists. Thus the effect of HK may depend upon the initial interaction at the platelet surface rather than later steps that are shared with a variety of other initiators. Although there are now data suggesting an interaction of $\mathrm{HK}$ with the GPIb-V-IX complex (9), these observations were obtained with the use of antisera to inhibit binding and no direct interaction of $\mathrm{HK}$ with components of this complex has yet been reported.

Use of the domain 3 peptide as a ligand for affinity chromatography leads to isolation of proteins at $45,68,72$, and $74 \mathrm{kD}$ by SDS gel electrophoresis; however, direct binding of the biotinylated peptide is observed only to the $74 \mathrm{kD}$ moiety. When native HK or factor XII was tested for binding to proteins isolated with the domain 3 peptide affinity column, binding occurred not only to the $74 \mathrm{kD}$ protein (GPIb) but also to proteins at 68 and $72 \mathrm{kD}$. Their identity is not known. Sites other than the domain 3-derived peptide may be involved in these interactions and HK may bridge these proteins so they are copurified. Alternatively, the proteins may be complexed with GPIb, so they are isolated via GPIb-peptide interaction. They may also represent GPIb that is further degraded but no longer interacts with our monoclonal anti-glycocalicin antibody. The latter two possibilities are favored because the same three bands are isolated by affinity chromatography using the anti-glycocalicin antibody rather than HK ligand affinity chromatography. The $45 \mathrm{kD}$ protein is identified as the PAR-1 thrombin receptor, but does not bind to any of the proteins tested here. The molecular weights observed for GPIb (74 kD) and the thrombin receptor $(45 \mathrm{kD})$ are lower than those reported for the purified proteins [GPIb (170 $\mathrm{kD})$, glycocalicin (135 kD), and thrombin receptor $(\sim 70 \mathrm{kD})](22,23)$. This appears to be due to proteolysis during platelet membrane purification, although we could not totally exclude the presence of a cross-reacting and thrombin-binding molecule of lower molecular weight. The thrombin receptor is known to undergo proteolysis to $42-45 \mathrm{kD}(23)$, as we observed it here, and the extracellular domain of the $\alpha$ chain of GPIb, which corresponds to glycocalicin, may be similarly cleaved.

We therefore next approached the binding by a method that does not require solubilization of cell membrane components-namely, pho- toaffinity labeling. As shown in Figure 6, the major binding protein for HK is GPIb, its molecular weight corresponds to that reported previously ( $135 \mathrm{kD}$ ), and the antibody to GPIb crossreacts with the anti-glycocalicin antibody utilized in the affinity experiments. Recently, Bradford et al. (10) have demonstrated that antisera to the GPIb-IX-V complex of platelets inhibit HK binding to platelets; our data are consistent with these observations and indicate that binding is to the $\alpha$ chain of GPIb. Thus binding to GPIb modulates functioning of the thrombin receptor. Functional linkage of GPIb and the thrombin receptor is also suggested by $\mathrm{HK}$ inhibition of aggregation with no discernable interaction with the thrombin receptor, as reported here. They were also co-isolated with our HK affinity column. A recent report suggests that factor XII may also inhibit thrombin-induced platelet aggregation (24), and we have demonstrated (Fig. 2) factor XII binding to GPIb as well.

The significance of HK (or factor XII) binding to GPIb is best appreciated by the binding inhibition study (Fig. 5) that demonstrates 55-60\% inhibition with a monospecific antibody directed to the $\alpha$ chain of GPIb. This same antiserum also identifies the $74 \mathrm{kD}$ band to which HK binds by ligand blot (Fig. 3) in a zinc-dependent reaction (Fig. 4). Since the plasma kininogens are substrates from which bradykinin is generated, their cell membrane expression may serve to modulate the delivery of this peptide to its receptor(s). Prekallikrein binds to HK, and both $\mathrm{HK}$ and factor XII bind to GPIb, thus all components of the kinin-forming cascade can be present along the surface of platelets. Binding of HK to GPIb may also sterically interfere with the ability of thrombin to cleave the thrombin receptor. Finally, $\mathrm{gClqR}$ has been shown to be a major HK binding protein of endothelial cells; however, it interacts with domain 5 rather than domain 3. Although platelets contain far less gClqR than do endothelial cells, we isolated it as a trace protein by photoaffinity labeling using native HK (Fig. 6B, lane 1) but not by ligand affinity chromatography with a domain 3 peptide.

\section{Acknowledgment}

We thank Dr. Barry Coller (Mount Sinai Medical Center, New York, NY) for his generous supply of antibody to glycocalicin. 


\section{References}

1. Silverberg M, Reddigari S, Kaplan AP. (1995) The contact system and its disorders. In: Handin RI, Lux SE, Stossel TP (eds). Blood-Principles and Practice of Hematology. J.B. Lippincott, Philadelphia, pp. 1129-1150.

2. Greengard JS, Griffin JH. (1984) Receptors for high molecular weight kininogen on stimulated washed platelets. Biochemistry 23: 6863-6869.

3. Jiang YP, Muller-Esterl W, Schmaier AH. (1992) Domain 3 of kininogens contains a cell binding site and a site that modifies thrombin activation of platelets. J. Biol. Chem. 267: 3712-3717.

4. Meloni FJ, Gustafson EJ, Schmaier AH. (1992) High molecular weight kininogen binds to platelets by its heavy and light chains and when bound has altered susceptibility to kallikrein cleavage. Blood 79: 1233-1244.

5. Reddigari SR, Kuna P, Miragliota G, Shibayama Y, Nishikawa K, Kaplan AP. (1993) Human high molecular weight kininogen binds to human umbilical vein endothelial cells via its heavy and light chains. Blood 81: 1306-1311.

6. Hasan AA, Cines DB, Herwald H, Schmaier AH, Muller-Esterl W. (1995) Mapping the cell binding site on high molecular weight kininogen domain 5. J. Biol. Chem. 270: 19256-19261.

7. Herwald H, Hasan AA, Godovac-Zimmerman J, Schmaier AH, Muller-Esterl W. (1995) Identification of an endothelial cell binding site on kininogen domain D3. J. Biol. Chem. 270: 14634-14642.

8. Puri RN, Zhou F, Hu C-J, Colman RW. (1991) High molecular weight kininogen inhibits thrombin-induced platelet aggregation and cleavage of aggregin by inhibiting binding of thrombin to platelets. Blood 77: 500-507.

9. Joseph K, Bahou W, Kaplan AP. (1997) Evidence that the zinc-dependent binding protein for Factor XII and high molecular weight kininogen is glycoprotein Ib [abstract]. J. Invest. Med. 45: $267 \mathrm{~A}$.

10. Bradford HN, Dela Cadena RA, Kunapuli SP, Dong J-F, Lopez JA, Colman RW. (1997) Human kininogens regulate thrombin binding to platelets through the glycoprotein $\mathrm{lb}-\mathrm{IX}-\mathrm{V}$ complex. Blood 90: 1508-1515.

11. Bahou W, Coller B, Potter C, Norton K, Kutok J, Goligorsky M. (1993) The thrombin receptor extracellular domain contains sites crucial for peptide ligand-induced activation. J. Clin. Invest. 91: 1405-1413.

12. Joseph K, Ghebrehiwet B, Peerschke EIB, Reid KBM, Kaplan AP. (1996) Identification of the zinc-dependent endothelial cell binding protein for high molecular weight kininogen and Factor XII: Identity with the receptor that binds to the globular heads of $\mathrm{Clq}(\mathrm{gClqR})$. Proc. Natl. Acad. Sci. U.S.A. 93: 8552-8557.

13. Nishikawa K, Shibayama Y, Kuna P, Calcaterra E, Kaplan AP, Reddigari SR. (1992) Generation of the vasoactive peptide bradykinin from human umbilical vein endothelium-bound high molecular weight kininogen by plasma kallikrein. Blood 80: $1980-1988$.

14. Proctor PR, Rapaport SI. (1961) The partial thromboplastin time with kaolin: A simple sceening test for first stage plasma clotting deficiencies. Am. J. Clin. Pathol. 35: 212-219.

15. Laemmli UK. (1970) Cleavage of structural proteins during the assembly of the head of bacteriophage T4. Nature 227: 680-685.

16. Bradford MM. (1976) A rapid and sensitive method for the quantitation of microgram quantities of protein utilizing the principle of proteindye binding. Anal. Biochem. 72: 248-254.

17. Smith PK, Krohn RI, Hermanson GT, et al. (1985) Measurement of protein using bicinchoninic acid. Anal. Biochem. 150: 76-85.

18. Coller BS, Peerschke EI, Scudder LE, Sullivan CA. (1983) Studies with a murine monoclonal antibody that abolishes ristocetin-induced binding of von Willebrand factor to platelets: Additional evidence in support of GP1b as a platelet receptor for von Willebrand factor. Blood 61: 99-110.

19. Coller BS, Kalomiris E, Steinberg M, Scudder LE. (1984) Evidence that glycocalicin circulates in normal plasma. J. Clin. Invest. 73: 794-799.

20. Wachtfogel YT, Dela Cadena RA, Kunapuli SP, et al. (1994) High molecular weight kininogen binds to MAC-1 on neutrophils by its heavy chain (domain 3) and its light chain (domain 5). J. Biol. Chem. 269: 19307-19312.

21. Reddigari SR, Shibayama Y, Brunnee T, Kaplan AP. (1993) Human Hageman Factor (Factor XII) and high molecular weight kininogen compete for the same binding site on human umbilical vein endothelial cells. J. Biol. Chem. 268: 11982-1 1987.

22. Steinberg MH, Kelton JG, Coller BS. (1987) Plasma glycocalicin - an aid in the classification of thrombocytopenic disorders. N. Engl. J. Med. 317: 1037-1042.

23. Vouret-Craviari V, Grall D, Chambard J-C, Rasmussen UB, Pouyssegur J, Van Obberghen-Schilling E. (1995) Post-translational and activationdependent modifications of the $G$ proteincoupled thrombin receptor. J. Biol. Chem. 270: 8367-8372.

24. Bradford HN, Pixley RA, Colman RW. (1998) Human Factor XII inhibits thrombin-induced platelet aggregation. Blood 92: 30a. 